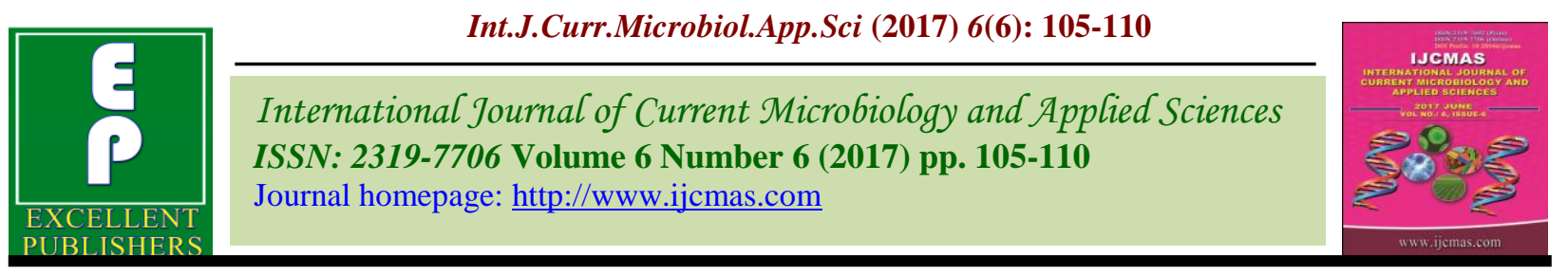

Original Research Article

https://doi.org/10.20546/ijcmas.2017.606.012

\title{
Effect of Sowing Methods and Foliar Nutrition for Maximizing the Productivity of Rice Fallow Blackgram (Vigna mungo L.)
}

\author{
J. Siva ${ }^{1}$, M. Hemalatha ${ }^{1^{*}}$ and M. Joseph ${ }^{2}$ \\ ${ }^{1}$ Department of Agronomy, Agricultural College and Research Institute, \\ Killikulam, Tamil Nadu, India \\ ${ }^{2}$ Agricultural Research Station, Kovilpatti - 628501 \\ Tamil Nadu Agricultural University, Thoothukudi District, Tamil Nadu, India \\ *Corresponding author
}

\begin{tabular}{|c|c|}
\hline & A B S T R A C T \\
\hline & Field experiment was conducted at Agricultural College and Research Institute, \\
\hline Keywords & $\begin{array}{l}\text { Killikulam (TNAU) during thaipattam (February } 2016 \text { - April 2016) to evaluate } \\
\text { the effect of sowing methods and foliar nutrition for maximizing the productivity }\end{array}$ \\
\hline Sowing method, & of rice fallow blackgram under combine harvested rice field. The experiment was \\
\hline $\begin{array}{l}\text { Nutrients and } \\
\text { growth regulators, }\end{array}$ & $\begin{array}{l}\text { laid out in Randomized block design and replicated thrice with twelve treatments. } \\
\text { The treatments involving broadcasting and dibbling methods of sowing and its }\end{array}$ \\
\hline $\begin{array}{l}\text { Foliar spray, } \\
\text { Yield of rice }\end{array}$ & combination with foliar application of nutrients and growth regulators sprayed on \\
\hline fallow pulses & $\begin{array}{l}30 \text { and } 45 \text { DAS. Among the treatments, dibbling method of sowing along with } \\
\text { foliar spray of TNAU pulse wonder } 1.125 \% \text { twice at } 30 \text { and } 45 \text { DAS recorded }\end{array}$ \\
\hline Article Info & significantly higher yield attributes viz., number of pod cluster plant ${ }^{-1}$, number of \\
\hline $\begin{array}{l}\text { Accepted: } \\
\text { 04 May } 2017\end{array}$ & $\begin{array}{l}\text { pods cluster }{ }^{-1} \text {, number of seeds pod }{ }^{-1} \text {, pod length and seed test weight and finally } \\
\text { the grain yield of } 692 \mathrm{~kg} \mathrm{ha}^{-1} \text {. It was followed by dibbling method of sowing along }\end{array}$ \\
\hline $\begin{array}{l}\text { Available Online: } \\
10 \text { June } 2017\end{array}$ & with foliar spray of polyfeed $1 \%+$ NAA $40 \mathrm{ppm}$ registered $642 \mathrm{~kg} \mathrm{ha}^{-1}$. The grain \\
\hline & $\begin{array}{l}\text { yield increases with these two treatments were } 54 \% \text { and } 42 \% \text { over the adoption } \\
\text { of dibbling method of sowing without any foliar nutrition }\left(449 \mathrm{~kg} \mathrm{ha}^{-1}\right) \text {. }\end{array}$ \\
\hline
\end{tabular}

\section{Introduction}

Pulses are an integral part of many diets across the globe and they have great potential to improve human health, conserve our soils, protect the environment and contribute to global food security. The United Nations declared 2016 as "International Year of Pulses" (IYP) to heighten public awareness of the nutritional benefits of pulses as part of sustainable food production aimed at food security and nutrition (Mohanty et al., 2015). India accounts for $33 \%$ of the world area and $22 \%$ of the world production of pulses. Due to stagnant production, the net availability of pulses has come down from $60 \mathrm{gm}$ in 1951 to 41.7 g/day/capita in 2016, as against Indian Council of Medical Research (ICMR) which recommends $65 \mathrm{~g} /$ day/capita. The total area under pulses in India is around 25.23 million hectares with a production of 19.27 million tonnes and productivity of $764 \mathrm{~kg} \mathrm{ha}^{-1}$ (Indiastat, 2014). In Tamil Nadu, blackgram is cultivated in 3.65 lakh hectares with the production of 3.10 lakh tonnes and an average productivity of $851 \mathrm{~kg} \mathrm{ha}^{-1}$ (Tnstat, 2014). 
This low yield is attributed to several reasons viz., low yielding varieties, cultivating in marginal lands mostly as rainfed crops and poor management practices. In Tamil Nadu rice fallow pulses contribute 40-50 per cent of total pulse production in which blackgram occupies a major share. The productivity of rice fallow black gram is always far below than it's normal cultivation (Sasikala et al., 2014). The main reasons for low productivity are poor plant population, poor nutrient and moisture stress under critical stages. Generally, rice fallow blackgram sowing will be carried out a week before harvest of rice. Nowadays, for harvesting of rice, combine harvesters were used, which make the soil to be compact and prevent seeds from establishment and even damage the emerged seedlings. To overcome these mechanical constraints, different methods of sowing were followed to make establishment of seeds. Apart from these, the physiological factors such as inefficient partitioning of assimilates, poor pod setting, excessive flower abscission and lack of nutrients during the critical stages of crop growth were found to be some of the yield barriers of pulses (Alberta and Bower, 1983; Promila Kumari and Varma, 1983).

Hence, Proper nutrient management is an important factor to be considered for sustaining pulse productivity. Among them foliar application of major nutrients like urea, DAP, $\mathrm{KCl}$ and Use of growth regulators are the potent force in improving the growth, flower initiation, pod setting, seed quality and yield of pulses.

\section{Materials and Methods}

Field experiment was carried out to evaluate the sowing methods and foliar nutrition for maximizing the productivity of rice fallow blackgram during thaipattam (February 2016April 2016) at Agricultural College and Research Institute, Killikulam. The texture of the surface soil $(0-15 \mathrm{~cm})$ of the experimental field was sandy clay loam and initial soil $\mathrm{pH}$, EC and organic carbon were 7.3, $0.28 \mathrm{dS} \mathrm{m}^{-1}$ and 0.68 per cent respectively. The fertility status was low in available nitrogen, medium in available phosphorus and available potassium. The experiment was laid out in Randomized block design with three replications. The treatments involving two methods of sowing of Broadcasting and Dibbling of seeds and its was followed with foliar spray of nutrients and growth regulators viz., Urea, DAP, $\mathrm{KCl}, \mathrm{KNO}_{3}, \mathrm{MAP}$, TNAU Pulse wonder, Polyfeed and plant growth regulator (NAA) were sprayed on 30 and 45 DAS. The blackgram variety ADT 3 was chosen for the study. Sowing was done at one day after combine harvest of rice. The yield attributing characters viz., number of pod cluster plant ${ }^{-1}$, number of pods cluster $^{-1}$, number of seeds pod $^{-1}$, pod length and seed test weight and also the yield of rice fallow pulses were recorded and the results are given below.

\section{Results and Discussion}

\section{Yield attributes}

The various yield attributing characters of rice fallow blackgram significantly differ due to crop establishment techniques and foliar spray of nutrients.

The number of pod cluster plant ${ }^{-1}$ significantly higher (9.9) when sowing of rice fallow pulses done by dibbling method coupled with foliar application of TNAU Pulse wonder $1.125 \%$. However it was on par with broadcasting method of sowing with foliar spray of TNAU Pulse wonder $1.125 \%$ and broadcasting method of sowing along with foliar spray of Polyfeed 1\% + NAA 40 ppm (9.6). The lower number of pod cluster plant $^{-1}$ (7.6) observed in broadcasting method of sowing without foliar nutrition. 
The maximum pod length $(5.3 \mathrm{~cm})$, the number of pods cluster-1 (4.2), the number of seeds $\operatorname{pod}^{-1}\left(6.6\right.$ seeds $\left.\operatorname{pod}^{-1}\right)$ and higher seed test weight $(3.8 \mathrm{~g})$ also influenced significantly when dibbling method of sowing along with foliar application of TNAU Pulse wonder $1.125 \%$ (Table 1 and Fig. 1). The increase in yield attributes due to dibbling method of sowing had an average higher plant population of (30.2 plants $\left.\mathrm{m}^{-2}\right)$ which assisted better translocation of photosynthates to the sink, resulting in more pods and higher grain weight compare to broadcasting method of sowing with foliar spray with an average plant population of 25.0 plants $\mathrm{m}^{-2}$. More over foliar application of TNAU Pulse wonder supplement the major and minor nutrients coupled with growth regulators enhanced the number of floral buds, prevented the floral shedding by maintaining optimum bio- physiological conditions in plants and also adequate nutrient availability through foliar nutrition promotes the supply of assimilates to sink or yield container, thus enlarging the size of the yield structure. The findings in this present study are in conformity with Hamid $e t$ al., (2002), Kalpana and Krishnarajan (2003), Hamayun and Chaudhary (2004) and Muhammad Hamayun et al., (2011).

\section{Grain, Bhusa and Haulm yield}

Adoption of different crop establishment techniques and foliar spray of nutrients has influenced the grain yield of rice fallow blackgram which ranged from 480-591 kg ha-1 in broadcasting method and 560-692 $\mathrm{kg} \mathrm{ha}^{-1}$ in dibbling method of sowing in irrespective of foliar nutrition (Table 2 and Fig. 2).

Table.1 Effect of sowing methods and foliar nutrition on yield components of rice fallow blackgram ADT 3

\begin{tabular}{|c|c|c|c|c|c|}
\hline Treatments & $\begin{array}{l}\text { No. of } \\
\text { pod } \\
\text { cluster } \\
\text { /plant }\end{array}$ & $\begin{array}{l}\text { Length } \\
\text { of pod } \\
\text { (cm) }\end{array}$ & $\begin{array}{l}\text { No. of } \\
\text { pods/ } \\
\text { cluster }\end{array}$ & $\begin{array}{l}\text { No. of } \\
\text { Seeds } \\
\text { /pod }\end{array}$ & $\begin{array}{l}100 \text { seed } \\
\text { weight } \\
\text { (g) }\end{array}$ \\
\hline $\mathrm{T}_{1}$-Broadcasting + FS of DAP $2 \%+$ NAA $40 \mathrm{ppm}$ & 8.1 & 4.8 & 3.6 & 5.0 & 3.5 \\
\hline $\begin{array}{l}\mathrm{T}_{2} \text {-Broadcasting }+ \text { FS of Urea } 1 \%+\text { DAP } 2 \%+\mathrm{KCl} 1 \%+\mathrm{NAA} \\
40 \mathrm{ppm}\end{array}$ & 8.7 & 4.5 & 3.4 & 5.2 & 3.5 \\
\hline $\mathrm{T}_{3}$-Broadcasting + FS of TNAU Pulse wonder $1.125 \%$ & 9.6 & 4.5 & 3.7 & 5.5 & 3.7 \\
\hline $\mathrm{T}_{4}$-Broadcasting + FS of Polyfeed $1 \%+$ NAA $40 \mathrm{ppm}$ & 9.6 & 4.5 & 3.7 & 5.4 & 3.6 \\
\hline $\mathrm{T}_{5}$-Broadcasting $+\mathrm{FS}$ of MAP $1 \%+\mathrm{KNO}_{3} 1 \%+\mathrm{NAA} 40 \mathrm{ppm}$ & 8.2 & 4.5 & 3.5 & 5.2 & 3.5 \\
\hline $\mathrm{T}_{6}$-Dibbling + FS of DAP $2 \%+$ NAA $40 \mathrm{ppm}$ & 9.5 & 4.5 & 3.4 & 5.4 & 3.6 \\
\hline $\begin{array}{l}\mathrm{T}_{7} \text {-Dibbling }+ \text { FS of Urea } 1 \%+\text { DAP } 2 \%+\mathrm{KCl} 1 \%+\mathrm{NAA} 40 \\
\mathrm{ppm}\end{array}$ & 8.3 & 4.6 & 3.4 & 5.4 & 3.7 \\
\hline $\mathrm{T}_{8}$-Dibbling + FS of TNAU Pulse wonder $1.125 \%$ & 9.9 & 5.3 & 4.2 & 6.6 & 3.8 \\
\hline $\mathrm{T}_{9}$-Dibbling + FS Polyfeed $1 \%+$ NAA 40 ppm & 9.0 & 4.9 & 4.1 & 5.8 & 3.8 \\
\hline $\mathrm{T}_{10}$-Dibbling + FS MAP $1 \%+\mathrm{KNO}_{3} 1 \%+\mathrm{NAA} 40 \mathrm{ppm}$ & 8.6 & 4.8 & 3.7 & 5.6 & 3.7 \\
\hline $\mathrm{T}_{11}$-Broadcasting without FS & 7.6 & 4.6 & 3.2 & 5.0 & 3.4 \\
\hline $\mathrm{T}_{12}$-Dibbling without FS & 7.7 & 4.6 & 3.3 & 4.9 & 3.4 \\
\hline $\begin{array}{l}\text { SEd } \\
\mathrm{CD}(\mathrm{P}=0.05)\end{array}$ & $\begin{array}{l}0.4 \\
1.0\end{array}$ & $\begin{array}{l}0.2 \\
0.4\end{array}$ & $\begin{array}{l}0.25 \\
0.52\end{array}$ & $\begin{array}{l}0.2 \\
0.4\end{array}$ & $\begin{array}{l}0.14 \\
\text { NS }\end{array}$ \\
\hline
\end{tabular}


Table.2 Effect of sowing methods and foliar nutrition on Grain, Bhusa, Haulm yield and harvest index of rice fallow blackgram ADT 3

\begin{tabular}{|c|c|c|c|c|}
\hline \multirow{2}{*}{ TREATMENTS } & \multicolumn{3}{|c|}{ Yield kg ha ${ }^{-1}$} & \multirow{2}{*}{ HI } \\
\hline & Grain & Bhusa & Haulm & \\
\hline $\mathrm{T}_{1}$-Broadcasting + FS of DAP $2 \%+\mathrm{NAA} 40 \mathrm{ppm}$ & 480 & 348 & 1302 & 0.22 \\
\hline $\begin{array}{l}\mathrm{T}_{2} \text {-Broadcasting }+\mathrm{FS} \text { of Urea } 1 \%+\mathrm{DAP} 2 \%+\mathrm{KCl} 1 \%+\mathrm{NAA} 40 \\
\mathrm{ppm}\end{array}$ & 531 & 384 & 1377 & 0.23 \\
\hline $\mathrm{T}_{3}$-Broadcasting + FS of TNAU Pulse wonder $1.125 \%$ & 591 & 408 & 1495 & 0.24 \\
\hline $\mathrm{T}_{4}$-Broadcasting + FS of Polyfeed $1 \%+\mathrm{NAA} 40 \mathrm{ppm}$ & 575 & 408 & 1394 & 0.24 \\
\hline $\mathrm{T}_{5}$-Broadcasting + FS of MAP $1 \%+\mathrm{KNO}_{3} 1 \%+\mathrm{NAA} 40 \mathrm{ppm}$ & 519 & 374 & 1345 & 0.23 \\
\hline $\mathrm{T}_{6}$-Dibbling + FS of DAP $2 \%+$ NAA $40 \mathrm{ppm}$ & 560 & 403 & 1463 & 0.23 \\
\hline $\mathrm{T}_{7}$-Dibbling $+\mathrm{FS}$ of Urea $1 \%+\mathrm{DAP} 2 \%+\mathrm{KCl} 1 \%+\mathrm{NAA} 40 \mathrm{ppm}$ & 613 & 412 & 1582 & 0.24 \\
\hline $\mathrm{T}_{8}$-Dibbling + FS of TNAU Pulse wonder $1.125 \%$ & 692 & 491 & 1805 & 0.23 \\
\hline $\mathrm{T}_{9}$-Dibbling + FS Polyfeed 1\% + NAA 40 ppm & 642 & 448 & 1650 & 0.23 \\
\hline $\mathrm{T}_{10}$-Dibbling + FS MAP $1 \%+\mathrm{KNO}_{3} 1 \%+\mathrm{NAA} 40 \mathrm{ppm}$ & 634 & 429 & 1602 & 0.24 \\
\hline $\mathrm{T}_{11}$-Broadcasting without FS & 418 & 295 & 1226 & 0.22 \\
\hline $\mathrm{T}_{12}$-Dibbling without FS & 449 & 319 & 1288 & 0.22 \\
\hline SEd & 23 & 16 & 66.8 & 0.01 \\
\hline $\mathrm{CD}(\mathrm{P}=0.05)$ & 48 & 34 & 145 & NS \\
\hline
\end{tabular}

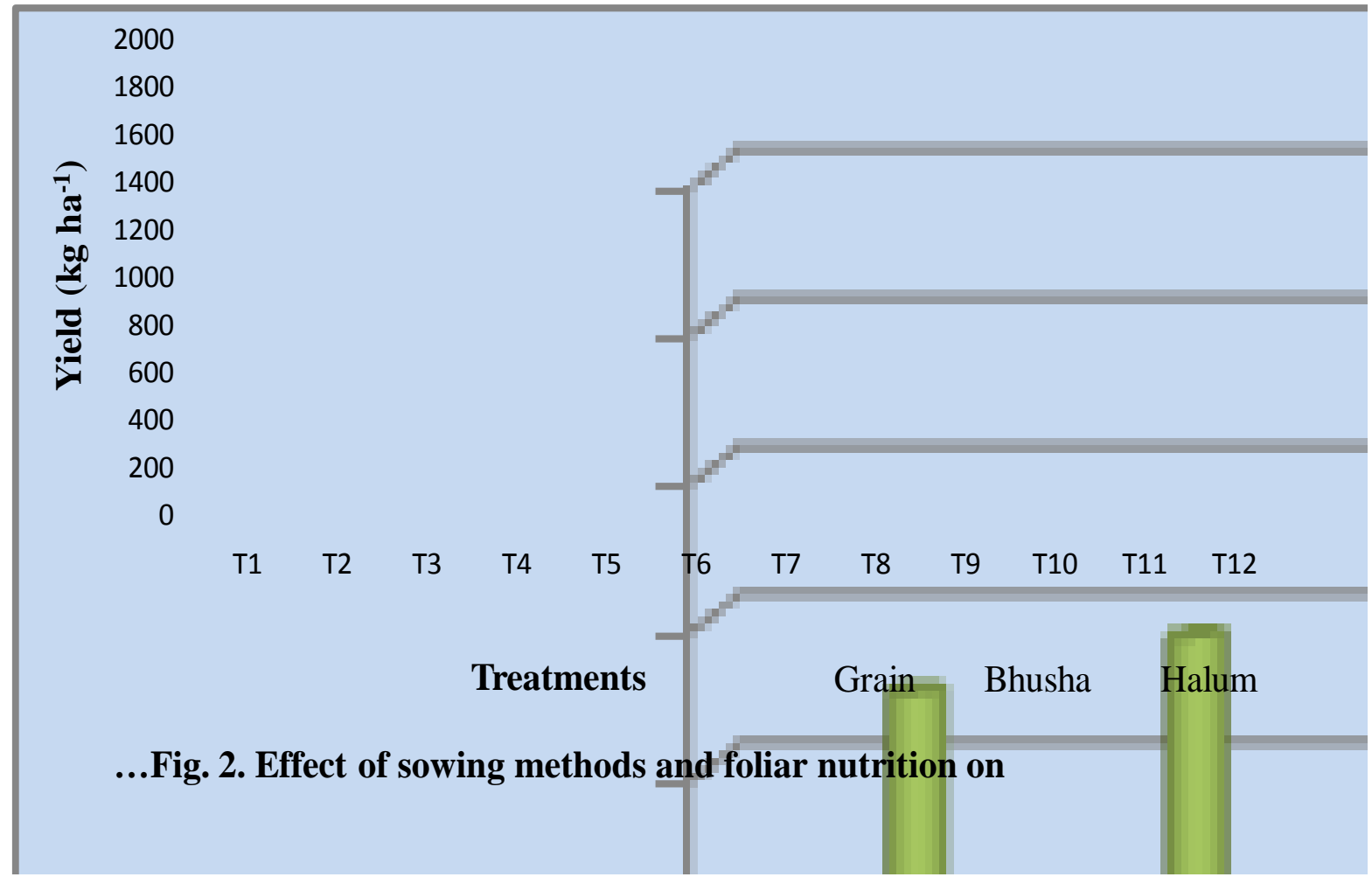




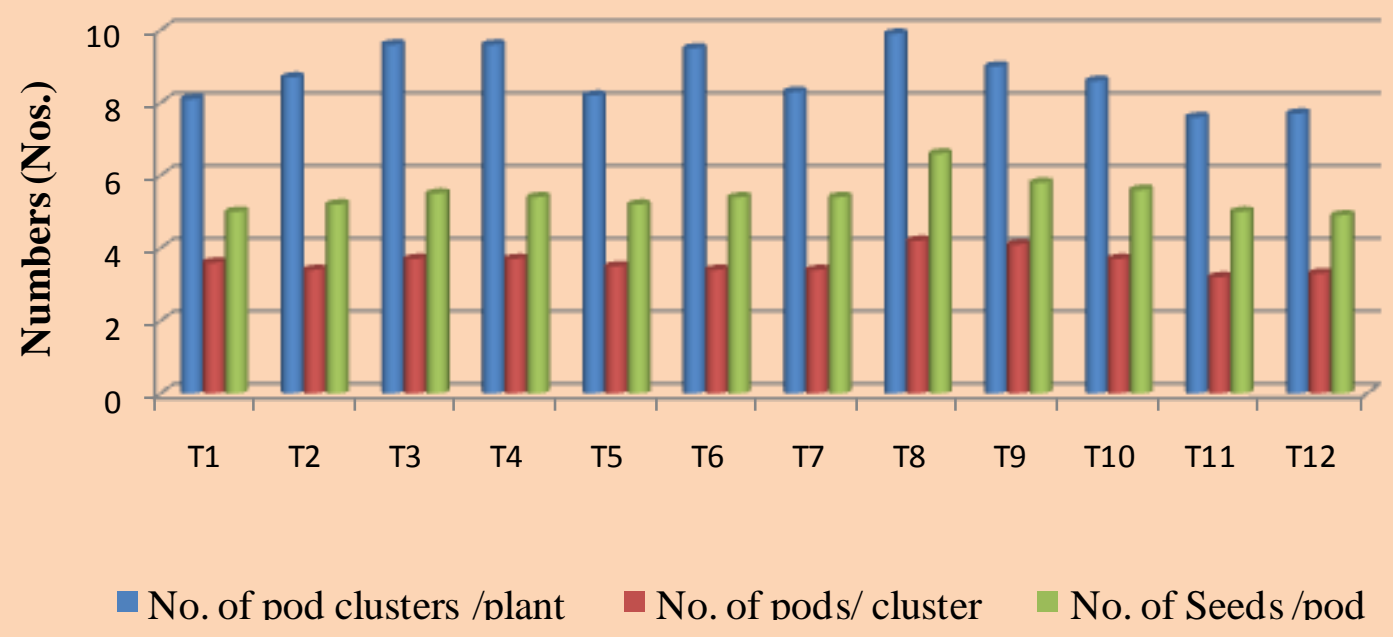

Fig. 1 . Effect of sowing methods and foliar nutrition on yield components of rice fallow blackgram

Dibbling method of sowing with foliar application of TNAU Pulse wonder1.125\% significantly recorded the higher grain yield of $692 \mathrm{~kg} \mathrm{ha}^{-1}$. It was followed by dibbling method of sowing along with foliar spray of polyfeed $1 \%$ + NAA 40 ppm registering 642 $\mathrm{kg} \mathrm{ha}^{-1}$. The grain yield increases with these two treatments were $54 \%$ and $42 \%$ over the adoption of dibbling method of sowing without any foliar nutrition (449 $\mathrm{kg} \mathrm{ha}^{-1}$ ). Broadcasting of rice fallow blackgram with foliar spray of TNAU Pulse wonder $1.125 \%$ twice at 30 and 45 DAS performed equally $\left(591 \mathrm{~kg} \mathrm{ha}^{-1}\right)$ when dibbling method of sowing with foliar spray of either MAP $1 \%+\mathrm{KNO} 3$ $1 \%+$ NAA 40 ppm $\left(634 \mathrm{~kg} \mathrm{ha}^{-1}\right)$ or Urea $1 \%$ + DAP $2 \%$ + KCl $1 \%$ + NAA 40 ppm $(613 \mathrm{~kg}$ $\left.\mathrm{ha}^{-1}\right)$. Sowing was done either broadcasting or dibbling without foliar spray treatment which received the grain yield of 418 and $449 \mathrm{~kg} \mathrm{ha}^{-1}$ respectively.

Similarly the Bhusa yield of rice fallow blackgram was also quite higher when the crop was sown by dibbling method followed by spraying of TNAU Pulse wonder $1.125 \%$ which recorded the Bhusa yield of $491 \mathrm{~kg} \mathrm{ha}^{-1}$. The lowest Bhusa yield of $295 \mathrm{~kg} \mathrm{ha}^{-1}$ was recorded in broadcasting method of sowing without any foliar nutrition.

The haulm yield was also enhanced due to adoption of same treatment which shows significantly higher Halum yield of $1805 \mathrm{~kg}$ $\mathrm{ha}^{-1}$ and it was followed by dibbling method of sowing along with foliar spray of polyfeed $1 \%$ + NAA $40 \mathrm{ppm}\left(1650 \mathrm{~kg} \mathrm{ha}^{-1}\right)$. Broadcasting method of sowing along with foliar spray of TNAU Pulse wonder $1.125 \%$ equally performed with dibbling method of sowing with foliar spray of MAP $1 \%+\mathrm{KNO}_{3} 1 \%+$ NAA 40 ppm

The yield increase in dibbling method of sowing and foliar spraying of TNAU Pulse wonder might be due to maintaining optimum plant population, reduced the flower droppings, improved the pod formation and seed setting percentage (Mir et al., 2010). Furthermore the impact of the foliar nutrients application (macro and micro) at the critical stage would have better growth and development of the crop and ultimately increasing the yield attributing characters and yield. This finding is in line with the results of Manivannan and Thanunathan (2003) who had recorded higher grain yield of blackgram by foliar application of microsol (NPK + 
micronutrients). The harvest index did not vary much between the method of sowing and foliar spray of nutrients which recorded from 0.22 to 0.24 in the rice fallow black gram variety ADT 3.

In conclusion, from the field experiment, it was concluded that dibbling method of blackgram sowing along with foliar application of TNAU Pulse wonder $1.125 \%$ significantly recorded the higher yield and yield attribute and it was followed by dibbling method of sowing along with foliar spray of polyfeed $1 \%+$ NAA 40 ppm under rice fallow condition.

\section{References}

Alberta, T.H and J.M.W. Bower. 1983. Distributionof dry matter and nitrogen betweendifferent plant parts in intact and depoddedsoybean plants after flowering. Netherlands. J. Agric. Sci., 31: 171-179.

Hamayun, M and M.F. Chaudhary. 2004. Effect of foliar and soil application of NPK on different growth parameters and nodulation in lentil. Sarhad J. Agric., 20: 103-111.

Hamid, M.A., M. Z. Islam, M.Biswas, A.A.Begum, M.Saifullah and M.Asaduzzaman. 2002. Effect of method of sowing and seed rate on the growth and yield of soybean. Pakistan J. of bio.Sci, 5(10): 1010 - 1013.

Indiastat. 2014. Online databases. In: http://www.indiastat.com

Kalpana, R and J. Krishnarajan. 2003. Effect of combined application of nutrients and hormones on soybean yield. Legume Res., 26(2): 151-152.

\section{How to cite this article:}

Siva J., Hemalatha M. and Joseph M.. 2017. Effect of Sowing Methods and Foliar Nutrition for Maximizing the Productivity of Rice Fallow Blackgram (Vigna mungo L.). Int.J.Curr.Microbiol.App.Sci. 6(6): 105-110. doi: https://doi.org/10.20546/ijcmas.2017.606.012
Manivannan, V and K. Thanunathan. 2003. Effect of foliar nutrition of major and chelated micronutrients and Rhizobium seed treatment on rice-fallow blackgram. Madras Agric. J., 90 (4-6): 344-347.

Mir, M., N.A. Mobin, M.A. Khan, N.A. Bhat, K.A. Lone, S.M. Bhat, S.A. Razvi,Wani, Nowsheeba Wani, Sabina Akhter, Shazia Rashid, Nasir Hamid Masoodi and W.A. Payne. 2010. Crop responses to interaction between plant growth regulators and nutrients. J. Phyto., 2(10): 9-19.

Mohanty, S and K.J.Satyasai. 2015. Feeling the pulse. NABARD Rural pulse, 10:14.

Muhammad Hamayun, Sumera Afzal Khan, Abdul Latif Khan, Zabta Khan Shinwari, Nadeem Ahmad, Yoon-Ha Kim and In-Jung Lee. 2011. Effect of foliar and soil application of nitrogen, phosphorus and potassium on yield components of lentil. Pak. J. Bot., 43(1): 391-396.

Promila Kumari and S. K. Varma. 1983. Genotypicdifferences in flower production, sheddingand yield in mungbean (Vigna radiata L.). IndianJ. Plant Physiol., 27: 402-405.

Sasikala. K., SNM Ramachandra Boopathi and P.Ashok. 2014. Evaluation of methods of sowing and post emergence herbicides for efficient weed control in zero till sown rice fallow black gram Vigna mungo L. Int. J. of Farm Sci.,4 (1): 81-91.

Tnstat. 2014. Online databases. In: http://www.tnstat.com. 